\title{
PEMIKIRAN PENDIDIKAN ASY-SYAUKĀNI DAN PERANANNYA DALAM MENCIPTAKAN RENAISSANCE
}

\author{
Anisah Setyaningrum \\ STAIN Purwokerto, Jawa Tengah, Indonesia. \\ anisahsetya17@gmail.com
}

\begin{abstract}
Artikel ini berupaya mengeksplor pemikiran pendidikan asySyaukāni dalam menciptakan kebangkitan dan kemajuan bangsa (renaissance). Yaitu dengan memaparkan situasi yang terjadi di Yaman pada saat itu, dan bagaimana peran asy-Syaukāni dalam upayanya membuat perubahan. Penelitian ini menggunakan pendekatan analis sejarah, yaitu dengan memaparkan kejadian dan peristiwa yang terjadi semasa asy-Syaukāni hidup, bagaimana kejadian ini berpengaruh padanya, dan bagaimana pula beliau memberi pengaruh pada masanya, kemudian dianalisis. Penelitian ini sampai pada kesimpulan bahwa: (1) asy-Syaukāni menyakini bahwa pendidikan memiliki peran besar dalam memajukan bangsa, (2) Asy-Syaukāni memiliki andil besar dalam membangun kebangkitan dan renaissance yang terlihat dari analisa beliau atas kondisi yang menimpa bangsanya, dan upaya beliau untuk mengubahnya, dengan cara memasukkan ilmu-ilmu baru, pendidikan menyeluruh, dan menuntut diberlakukannya pendidikan untuk kaum hawa, (3) pemahaman tentang renaissance asy-Syaukāni berbeda dengan renaissance Barat, yang mana agama tetap tidak bertentangan dengan ilmu pengetahuan, bahkan menyuruh untuk berpikir karena menghomati akal.
\end{abstract}

Kata kunci: pemikiran, pendidikan, asy-Syaukāni, renaissance 


\begin{abstract}
THE EDUCATION THOUGHT OF AL-SHAWKAANI AND ITS ROLE IN CREATING A RENAISSANCE. This article attempts to explore the educational thought of Al-Shaukani in creating the rise and progress of Nations (renaissance). By exposing the situation that happened in Yemen at the time, and how the role of Al-Shaukani in an attempt to make the change. This research uses the approach of historical analysis, by exposing the events that occur during AlShaukani life, how this incident was influential on him, and how he gave influence in his time, and then analyzed. The study came to the conclusion that: (1) Al-Shaukani believed that education has a major role in advancing the nation, (2) Al-Shawkaani has a major role in building the revival and renaissance which is seen from his analysis of the condition that afflicts his people, and his effort to change it, by instilling the new sciences, a thorough education, and demanded the enactment of the education for womenfolk, (3) an understanding of the renaissance of Al-Shaukäni in contrast to the Western renaissance, which the religion does not conflict with science, even told he ordered the people to think honor the sense.
\end{abstract}

Keywords: educational thought, Al-Shaukāni, renaissance

\title{
A. Pendahuluan
}

Islam pernah memiliki peradaban yang menjulang dan mencapai puncak kejayaannya pada abad ke $14 \mathrm{H}$. Hal ini lantaran kuatnya dorongan internal dan banyaknya nilai-nilai serta perangkat yang dibawa oleh Islam, seperti memuliakan manusia dan menempatkannya di posisi yang paling tinggi dari sekian makhluk, menjunjung tinggi akal, memuliakan hak perempuan, dorongan untuk terus berpikir dan bertadabbur, serta nilai-nilai lainnya. Peradaban ini diraihnya dari hasil keterbukaan Islam dalam memanfaatkan peradaban bangsa-bangsa sebelumnya, seperti Romawi, Yunani, Persia dan lain sebagainya. Peradaban-peradaban ini oleh Islam diadopsi dan diperbaiki, sehingga menghasilkan peradaban tersendiri yang banyak memberikan sumbangsih besar dalam kehidupan manusia. Namun, perlu dicacat, peradaban Islam ini lambat laun mengalami kemunduran lantaran beberapa faktor, seperti pergolakan politik, pertikaian madzhab, dan kejumudan dalam berpikir. Di waktu 
yang sama, Eropa mulai terbangun dari tidurnya. Ia menemukan jati dirinya, dan mulai terbuka dengan peradaban-peradaban bangsa lain. Ia menghidupkan kembali apa saja yang dahulu menjadi penyebab kemajuan bangsa Yunani dan Romawi. Gerakan ini disebut era kebangkitan Eropa, atau yang dikenal dengan istilah Renaissance (Glorier, 1983: 65).

Di saat Eropa mulai bangkit, dunia Arab justru mengalami kemunduran. Mereka menutup pintu ijtihad dalam fikih, menolak filsafat dan logika, khurafat semakin merebak, pertikaian antar madzhab, dan masih banyak kejadian lainnya yang menimpa dunia Islam saat itu. Yaman, yang merupakan salah satu negara Islam saat itu tidak luput dari kejadian-kejadian tersebut. Negara mengalami kemunduran. Dan, inilah yang memanggil jiwa asy-Syauka $>$ ni untuk turut serta memberikan sumbangsih pemikiran dalam rangka menuju perubahan.

\section{B. Pembahasan}

\section{Biografi Asy-Syaukāni}

Asy-Syaukāni lahir di bulan Dzul Qa'dah pada tahun 1173 H/1760 M. Di daerah Syaukan yang terletak di sebelah tenggara kota Sana'a, Yaman. Kota inilah yang menjadi julukan beliau. Beliau lahir di dalam keluarga intelektual. Ayahnya, Ali bin Muhammad atau yang dikenal dengan nama Ali Asy-Syaukāni (1130-1211) merupakan orang yang piawai dalam berbagai disiplin ilmu. Bahkan, pada masanya, beliau memiliki kedudukan yang terhormat dengan menjabat sebagai qadhi akbar (hakim agung) pada pemerintahan alMahdi, sekaligus juga sebagai pengajar. Faktor lingkungan keluarga inilah yang berperan besar mencetak asy-Syaukāni kecil menjadi ulama besar di masa depan. Sedari kecil, asy-Syaukāni hidup dalam lingkungan intelektual yang jauh dari sikap taklid dan lebih berpegang pada ijtihad. Hal ini dikarenakan lingkungan keluarga yang bermadzhab Zaidiyyah yang cenderung fokus pada ijtihad fikih. Sikap seperti ini sudah menjadi tuntutan bagi mereka yang hendak memangku jabatan imam. Lingkungan inilah yang membentuk 
intelektual asy-Syaukāni sehingga sampai pada level seorang mujtahid mutlak (Bukrusyah, 2002: 32).

Sebelum beliau, banyak bermunculan para tokoh mujtahid. Mereka banyak mewarnai lingkungan intelektual di Shana'a. Mereka semua adalah seorang mujaddid, mujtahid dan revolusioner, sehingga upaya tajdid (pembaruan) yang dilakukan asy-Syaukāni masih ada ikatannya dengan para ulama sebelumnya. Tokoh-tokoh tersebut antara lain adalah Muhammad bin Ibrahim al-Wazir $(840 \mathrm{H}$.), alHusain Ahmad al-Jalal (1084 H.), Muhammad bin Ismail al-Amir (1182 H.), dan al-Hasan bin Mahdi al-Muqbili (1108 H.) keempat tokoh tersebut menerangi Yaman dengan pemikiran-pemikiran mereka serta perjuangan mereka melawan fanatisme dan kejumudan (al-Maqalih, 1982: 84).

Asy-Syaukāni kecil mengawali perjalanan intelektualnya dengan memakai metode yang diikuti oleh negara-negara Islam saat itu, yaitu pertama kali belajar al-Quran dengan tajwidnya kepada seorang Syaikh/guru. Asy-Syaukāni sendiri telah berhasil menghafal al-Quran, kemudian hafal beberapa kitab ringkasan tentang ilmu bahasa, fikih, sejarah dan kitab-kitab sastra. Sehingga periode pertama dalam pembelajaran beliau adalah talqiniyyah (dikte) lalu beranjak pada fase pemahaman dan penguasaan materi. Setelah menyelesaikan pendidikan fase pertamanya, asy-Syaukāni mulai menimba ilmu kepada ayahnya dan para ulama pada masanya. Beliau menekuni berbagai disiplin ilmu, seperti ilmu agama, bahasa, matematika dan falak. Ilmu-ilmu inilah yang berkembang pada saat itu. Meski demikian, asy-Syaukāni tidak tunduk pada metode belajar konvensional yang sudah berkembang pada masa itu. Beliau memiliki metode tersendiri dalam menuntut ilmu, sehingga hal inilah yang menjadikan beliau mampu menguasai banyak disipilin ilmu dalam usia muda. Selain menggunakan metode pembelajaran konvensional yang sangat marak pada saat itu, seperti saat belajar menghafal Alquran dan menghafal ringkasan kitab matan di berbagai disiplin ilmu, asy-Syaukāni mengembangkan metode pembelajaran baru sebagaimana berikut (Bukrusyah, 2002: 53-62): 
a. Mempelajari satu kitab kepada lebih dari satu guru (Syaikh). Metode seperti ini dapat menghindarkan seorang penuntut ilmu bertaklid buta pada guru dan cenderung fanatis. Dengan belajar kepada banyak guru pada satu kitab, maka seorang penuntut ilmu akan lebih kritis dan analisis, di samping ia mampu membandingkan materi yang disampaikan dan metode mereka.

b. Belajar mandiri. Asy-Syaukāni juga memelari beberapa disiplin ilmu secara mandiri tanpa bimbingan seorang guru, seperti ilmu alam, astronomi dan lain sebagainya (asy-Syaukāni, 1988: 154). Metode seperti ini memungkinkan asy-Syaukāni untuk selalu mengikuti perkembangan hal-hal baru.

c. Mengajarkan ilmu kepada teman belajarnya. Selain belajar dari gurunya, asy-Syaukāni juga mengajarkan apa yang dipelajarinya kepada teman-temannya. Metode seperti merupakan cara beliau me-review materi sekaligus untuk menilai sejauh mana pemahamannya terhadap materi yang dipelajari.

d. Melakukan diskusi dengan beberapa syaikh, terlebih setelah banyak menerima ilmu. Hal ini dapat mengasah kekritisan beliau, di samping untuk memotivasi beliau dalam mengkaji ilmu dan berkarya (Asy-Syaukāni, 1929: 18).

Metode-Metode tersebut di atas telah memberi pengaruh luar biasa terhadap asy-Syaukani, sehingga tidak hanya menguasai ilmu-ilmu agama, asy-Syaukāni juga membuka diri terhadap ilmuilmu sosial, seperti sejarah, pendidikan dan ilmu-ilmu akal, semisal matematika, alam, dan teologi (asy-Syaukāni, 1988: 182).

\section{Keterkaitan antara Pendidikan dan Kebangkitan Sebuah Bangsa (Renaissance)}

Pendidikan merupakan suatu yang sangat penting. Begitu pentingnya sebuah pendidikan, Rasulullah sendiri sampai mewajibkan umatnya untuk menuntut ilmu sepanjang hayat. Hal ini tidak lain demi menciptakan kader-kader umat yang berpendidikan. Bahkan, jika melihat sejarah banyak para ulama Islam terdahulu yang rela menempuh ribuan kilometer, dan bahkan hingga ke luar negeri dengan perjalanan berhari-hari demi mendapatkan ilmu. Para pakar pendidikan dan pemikiran berbeda pendapat terkait peran 
pendidikan dalam merubah dan membangun masyarakat. Dalam hal ini muncul tiga pendapat. Pertama; pendidikan bisa mengubah suatu masyarakat, kedua; pendidikan tidak dapat mengubah masyarakat, ketiga; keduanya saling mempengaruhi (Daim, 1991: 2-5). Berikut ini dijelaskan secara rinci ketiga pendapat tersebut.

Kelompok pertama berpendapat, bahwa pendidikan mampu mengubah tatanan masyarakat. Orang yang berpendapat demikian adalah Rousseau, yang sebelumnya didengungkan oleh Plato dan Emanuel Kant. Mereka berpendapat, bahwa untuk memperbaiki lembaga-lembaga masyarakat haruslah dimulai dari perbaikan pendidikan. Pendapat ini juga didukung oleh Rogers. Mereka menyakini betul bahwa pendidikan berperan penting dalam mengubah masyarakat.

Kelompok kedua berpendapat bahwa pendidikan tidak dapat mengubah tatatan masyarakat. Sebaliknya, pendidikan sendiri yang tunduk kepada masyarakat. Menurut mereka, negara yang menentukan arah dan tujuan pendidikan, bukan sebaliknya. Tokoh yang berpendapat seperti ini adalah Dorkheim. Dalam pandangan mereka, selagi pendidikan tidak mampu mengubah masyarakat maka kita harus mengubah terlebih dahulu bangunan masyakarat itu sendiri.

Kelompok ketiga berpendapat, baik pendidikan dan masyarakat saling mempengaruhi. Artinya, pendidikan bisa merubah masyarakat, dan sebaliknya masyarakat juga bisa mengubah pendidikan. Pendidikan memiliki andil dalam mengubah masyakat tapi bukan satu-satunya, ada sistem lain yang juga ikut mendukungnya. Kelompok ini berpendapat, bahwa hubungan antara pendidikan dan masyakarat bukanlah hubungan sebab akibat, melainkan hubungan keterpengaruhan.

Setelah memaparkan berbagai pandangan ilmuwan Barat tentang peran pendidikan dalam memunculkan pembaruan dan kebangkitan, yang menjadi pertanyaan kita adalah apakah asySyaukāni juga mengamini bahwa pendidikan berperan dalam 
memunculkan pembaruan dan kebangkitan? Bagaimana beliau memandang peran pendidikan dalam perubahan ini?

\section{Peran Pendidikan dalam Menciptakan Kebangkitan (Renaissance) menurut Pandangan Asy-Syaukāni}

Asy-Syaukāni berpendapat bahwa pendidikan merupakan pondasi yang kuat dan tiang-tiang penyokong sebuah kebangkitan dan perubahan. Perubahan ini mencakup semua aspek, baik politik, ekonomi, sosial dan budaya. Hal ini terlihat jelas dari pemaparan asy-Syaukāni atas keterbelakangan yang menimpa masyakaratnya dalam berbagai sendi-sendi kehidupan. Keterbelakangan ini, menurut pandangan asy-Syaukāni lantaran disebabkan oleh kebodohan dan kurangnya ilmu. Kebodohan ini tidak hanya menjangkiti kaum awam saja, melainkan merambah pula kalangan petinggi masyakarat, seperti para pejabat, qadhi (hakim), dan para cendekiawan. Kebodohan mereka, dalam pandangan asy-Syaukāni, bukan lantaran mereka buta wawasan, melainkan karena mereka tidak sanggup membawa perubahan. Alih-alih membawa perubahan, justru mereka menyebarkan kezaliman, mengusik HAM dan tidak menegakkan keadilan.

Melihat fenomena yang menjangkiti masyakaratnya ini, maka asy-Syaukāni berupaya memberikan solusi, yaitu menyebarkan pendidikan secara menyeluruh hampir di seperempat negeri Yaman, baik di daerah perkotaan maupun pedesaan. Pendidikan yang ingin disebarkan oleh asy-Syaukāni adalah pendidikan yang tidak berbasis atas taklid, tidak fanatis, bukan ilmu yang lebih mendahuluan hal sekunder dibandingkan hal primer, dan lain sebagainya yang menyebabkan keterbelakangan pendidikan pada saat itu. Melihat keterpurukan saat itu, maka yang pertama kali dilakukan asy-Syaukāni adalah membenahi pendidikan itu sendiri. Dari sini, beliau kemudian mengarang kitab yang berjudul "Adab ath-Thalab wa Muntaha alArib" yang berisikan bagaimana seorang penuntut ilmu bisa meraih ilmu yang sebenarnya, baik secara tujuan, metode maupun isi (asySyaukāni, 1988: 73-141).

Selain itu, asy-Syaukāni tidak lupa menjelaskan unsur syar'i 
dalam mencari ilmu. Menurut asy-Syaukāni, mencari ilmu adalah ibadah. Bahkan termasuk ibadah yang paling mulia dan agung (asySyaukāni, 1988). Mengingat ia merupakan ibadah, maka mencarinya dituntut adanya keikhlasan. Sebab, ibadah tanpa dilandasi keikhlasan tidak akan diterima. Demi membela gagasannya tentang pentingnya penyebaran ilmu, maka asy-Syaukāni tidak menerima gagasan bahwa ilmu hanya terbatas pada kelompok tertentu saja (asySyaukāni, 1929: 76).

Adapun ilmu yang dianjurkan oleh asy-Syaukāni untuk dikembangkan dan disebarluaskan adalah semua ilmu, tidak hanya terbatas pada tataran ilmu syara' saja. Akan tetapi dengan syarat, ilmu syara' harus mendominasi dan menjadi pengarah bagi ilmu lain. Gagasan seperti ini sejalan dengan apa yang diyakini asy-Syaukāni bahwa Islam adalah agama yang komprehensif (syumūliyyatul Isläm). Ilmu apapun yang dipelajari pada akhirnya haruslah digunakan demi berkhidmat pada agama dan individu guna meraih kebahagiaan di dunia maupun akhirat. Karenanya, asy-Syaukāni membolehkan seseorang memelajari ilmu lain setelah ia mendalami ilmu syara', supaya pelajar tadi tidak tergelincir dan mengalami kebingungan (asy-Syaukāni, 1988: 145-153).

Asy-Syaukāni meyakini betul pentingnya pendidikan yang holistik, dan menurutnya, ia merupakan solusi atas penyakit masyakarat Yaman pada waktu itu. Kondisi ini dipaparkan oleh asySyaukāni dalam bukunya yang berjudul “ad-Dawa' al-Ajil fi Daf'i alAduwwi ash-Shail serta dijelaskan dalam kitab-kitab beliau lainnya (asy-Syaukāni, 1994: 59-73).

Untuk mengatasi keterpurukan yang menimpa Yaman pada saat itu, asy-Syaukāni memberikan solusi berikut:

a. Seruan (ajakan) melakukan pendidikan secara menyeluruh, di mana asy-Syaukāni mengajak supaya negara (pemerintah) menentukan pengajar pada tiap-tiap kota (desa).

b. Beliau juga mengemukakan ide yang sekarang ini disebut dengan istilah 'Demokrasi Pendidikan'. Artinya, negara wajib menentukan para pengajar di tiap-tiap desa tanpa ada 
diskriminasi. Asy-Syaukāni mengajak supaya negara juga memperhatikan pendidikan yang ada di desa-desa. Hal ini karena mayoritas negara lebih memperhatikan pendidikan yang ada di kota. Akibatnya, terjadi ketimpangan antara masyarakat desa dan kota. Oleh karena itu, untuk menanggulanginya pemerintah (negara) harus berlaku adil dan tidak diskriminatif.

c. Asy-Syaukāni menyerukan gagasan wajib belajar. Pemerintah harus menjamin terealisasinya ide ini, dan memenjarakan siapa saja yang menolaknya.

d. Beliau juga menyerukan, bahwa seorang pengajar haruslah orang yang salih dan sadar akan ideologi Islam dan bisa mengaplikasikannya. Sehingga, tidak ada lagi dikotomi antara ilmu (sains) dan agama dalam pendidikan Islam, atau antara ilmu pengetahuan (sains) dan etika Islam (Asy-Syarji, 1988: 379).

Asy-Syaukāni menyerukan pentingnya menyebarkan ilmu yang sebenarnya, yang tidak ada khurafat, bid'ah dan taklid. Karenanya, beliau sangat perhatian betul terhadap ilmu-ilmu ijtihad, dan mengajak para penuntut ilmu untuk memelajarinya. Sebab, ilmu ijtihad inilah merupakan sarana paling efektif agar mampu membedakan mana yang benar dan mana yang salah. Beliau menyeru supaya para da'i dan pengajar harus dibekali wawasan yang memadai, sehingga posisi tersebut tidak diisi oleh orang-orang bodoh yang bisa menghancurkan bangsa. Terlebih lagi, mereka adalah panutan umat. Sehingga, segala gerak gerik mereka selalu diamati dan diikuti oleh masyarakat.

Di sisi lain, asy-Syaukāni juga tidak setuju dengan orang-orang alim (cendekiawan) yang zahid dan tidak mau memangku jabatan (di pemerintahan). Sebab, hal itu bisa membahayakan masyarakat bila posisi tersebut diisi oleh orang-orang yang bukan ahlinya. Oleh karena itu, beliau menyarankan betul kepada orang-orang cendekia yang diakui keilmuannya supaya mau maju untuk memangku jabatan agar bisa menciptakan perubahan-perubahan yang diinginkan (asySyaukāni, 1988: 186).

Peran penting sebuah pendidikan dalam pandangan asy- 
Syaukāni terlihat jelas saat ia menjelaskan bahwa pertikaian yang terjadi di masyarakat semakin meruncing ketika dalam suatu masyarakat tersebut terdapat sekelompok orang yang memiliki ilmu dangkal namun mengaku sebagai ulama, padahal mereka bukan tergolong ulama yang diperhitungkan ucapannya, juga bukan orang awam yang ditolelir kebodohannya. Selain itu, pendidikan -dalam pandangan asy-Syaukāni- merupakan faktor penyebab kestabilan politik. Sebab, sebuah negara yang mau mendidik rakyatnya, menghapus buta huruf dan mensupport keberlangsungan pendidikan bisa berimbas pada kestabilan politik. Sebaliknya, dengan adanya kestabilan politik, maka negara mampu memberikan pelayanan pendidikan yang menyeluruh, baik di tingkat desa maupun kota. Sehingga, ketika suhu politik stabil, dan tidak ada kisruh di dalam suatu negara, maka memungkinkan bagi negara tersebut untuk bergerak maju dan berkembang.

\section{Menciptakan Kebangkitan (Renaissance) dalam Pandangan Asy-Syaukāni}

Sebagaimana dimaklumi, suatu bangsa ketika menyadari bahwa dirinya mengalami ketertinggalan dan keterpurukan, pasti ia akan berpikir untuk melakukan suatu perubahan. Tentu saja, orang yang membangun dasar-dasar perubahan tersebut adalah para pemikir dan cendekiawannya. Inilah yang sudah dirasakan oleh asySyaukāni, sehingga beliau mencetuskan beberapa solusi yang mampu mengubah suatu bangsa dari keterpurukan. Solusi yang diberikan asySyaukāni antara lain adalah 1) memahami realita dan menganalisanya; 2) menerapkan pendidikan holistik dan memasukkkan ilmu-ilmu baru; 3) memperbaiki metode pembelajaran; 4) pendidikan untuk perempuan.

a. Memahami realita dan menganalisisnya

Mengetahui realita adalah sesuatu yang wajib bagi orang yang hendak mengubah masyarakat dan membangkitkannya. Hal ini tentu saja untuk mengambil sisi positif dari realita ini dan menghindari sisi negatifnya. Lantas, realita apa yang terjadi pada saat itu, sehingga asy-Syaukāni memikirkan langkah untuk mengubahnya? Berikut ini beberapa realita yang terjadi saat itu 
sebagaimana sehingga memaksa asy-Syaukāni untuk bertindak.

b. Jumud (berpikir stagnan) dan takhalluf (terbelakang)

Setelah melihat kondisi dunia pendidikan yang menimpa para pelajar pada zamannya yang cenderung taklid buta, fanatik, mengedepankan ilmu sekunder dibanding ilmu primer, serta hal-hal lain yang menunjukkan keterbelakangan, maka dalam kitabnya Adab ath-Thalab wa Muntaha al-Arab asy-Syaukāni hendak menyadarkan dan membimbing para pelajar pada metodologi ilmiah yang benar yang seharusnya mereka tempuh guna sampai pada tingkatan ilmu yang beragama. Kejumudan dan hilangnya kreatifitas dapat pandangan asy-Syaukāni ini yang menjadikan bangsa menjadi terbelakang. Oleh karenya, agar bangsa menjadi maju, maka sikap ini harus dihilanhkan (adDaim, 1991: 14).

c. Tidak mau menerima peradaban lain Jika ditelaah, salah satu sebab kuatnya peradaban Islam pada eraera awal adalah keterbukaan Islam terhadap peradaban bangsa lain, seperti Yunani, Persia, dan India. Inilah rahasia kekuatan peradaban Islam saat itu. Banyak peradaban lain yang diserap dan dikembangkan oleh Islam sehingga muncul produk baru dengan cita rasa Islam dan berbahasa Arab. Pada era kemunduran, umat Islam hanya puas dengan apa yang dimilikinya saja dan tidak mau terbuka menerima kemajuan peradaban lain. Hal ini kemudian disadari betul oleh asy-Syaukāni, sehingga beliau menyerukan untuk bersikap terbuka dan memasukkan ilmu-ilmu baru dalam pendidikan.

d. Sikap fanatik

Sikap fanatik inilah merupakan musykilah (problem) terbesar yang menghambat kemajuan intelektual. Sebab, orang yang fanatis tidak bisa melihat kebenaran dan yang hak, kecuali bila itu ada keuntungan untuk dirinya atau keuntungan untuk kabilahnya, atau keuntungan untuk mazhabnya. Problem ini problem sikap fanatis - pernah merambah di negeri Yaman pada abad 19 dikarenakan masyarakat terbagi menjadi dua mazhhab: Syiah Zaidiyyah dan Suni. Oleh karena itu, problem ini menjadi perhatian yang cukup serius oleh asy-Syaukāni sebagaimana dalam kitab "Adab ath-Thalab" dan memasukkan sikap fanatik ini sebagai bahaya bagi penuntut ilmu. Asy-Syaukāni sangat gencar 
memerangi sikap fanatik ini dan mengajak pada penunutut ilmu agar menjauhinya. Ketika membahas tentang metode berpikir ilmiah yang benar, salah satu caranya adalah menghilangkan sikap fanatik. Caranya adalah dengan berpikir kritis, dan melatih siswa sejak dini untuk mengikuti manhaj ilmi as-salim - pola ilmiah yang benar - dan tidak gampang menerima ilmu kecuali setelah dikajinya. Mungkin ini yang membuat asy-Syaukāni tercatat dalam deretan para pemikir Islam yang getol dalam menyuarakan rasionalitas. Sehingga, asy-Syaukāni dikenal sebagai ulama yang rasionalis.

e. Menjalarnya taklid dan menolak perubahan

Ketika kebodohan semakin merajalela, ruh kreatifitas semakin luntur, dan umat sendiri tidak mau terbuka terhadap golongan lain, maka sikap taklid semakin merajalela, dan ajakan untuk berbenah dan berubah pun ditolak. Padahal, al-Qur'an sendiri memberi peringatan yang begitu keras terhadap sikap ini serta mengecam para mukallid (Ali Imran: 170-171). Seorang mukallid adalah mereka yang mengikuti orang lain tanpa ditelaah terlebih dahulu, ia tidak mau menggunakan akal dan pikirannya. Alquran sendiri menyerupakan seorang mukallid pada ayat di atas dengan binatang yang mau menuruti apa saja yang dikatakan oleh penggembalanya.

Melihat begitu berbahayanya sikap taklid ini, maka bisa dilihat bahwa asy-Syaukāni sangat memerangi sikap taklid ini. Bahkan, beliau menyeru dengan lantang dan tegas untuk memerangi taklid ini sebagaimana hal ini terlihat jelas pada sikap rasional beliau.

f. Lemah dan sedikitnya kaum terpelajar

Tidak dipungkiri, bahwa kelompok terpelajar dalam suatu masyarakat adalah mereka yang punya andil besar dalam kebangkitan. Di pundak merekalah kebangkitan bisa digerakkan. Inilah yang membuat asy-Syaukāni memusatkan perhatiannya untuk menyebarkan pendidikan ke seluruh kota dan desa. Hal ini dilakukannya karena ia yakin pendidikan memiliki peran dalam perubahan. Dan, perubahan sendiri tidak akan terjadi tanpa adanya kelompok atau kaum terpelajar yang memangku tanggung jawab dalam menyebarkan pendidikan dan menerjemahkan ilmu-ilmu dari bangsa lain. 
g. Pendidikan secara holistik dan memasukkan ilmu-ilmu baru Kebangkitan tidak akan terjadi tanpa adanya pendidikan yang holistik dan menyebarkannya ke seluruh lapisan masyarakat. Sebab, kebangkitan itu mustahil terjadi jika tidak ada keterlibatan seluruh aspek masyarakat, hal ini bisa dilakukan dengan cara menyebarkan pengajaran, dan ilmu yang diajarkan juga harus menyeluruh, tidak hanya terbatas pada aspek teoritis saja atau aspek materiil. Akan tetapi, mencakup pola ilmu sosial, ilmu alam, dan matematika. Yaitu dengan cara memasukkan ilmu-ilmu tersebut dalam kurikulum pendidikan atau dengan memanfaatkan apa yang dimiliki bangsa lain, dengan cara menyalin, menerjemah dan mengirim duta.

Asy-Syaukāni sadar betul pentingnya penyebaran pendidikan sebagai syarat wajib untuk memunculkan perubahan yang diinginkan. Dalam pemikiran pendidikannya, asy-Syaukāni berpendapat bahwa melalui ilmu memungkinkan untuk memerangi sikap bermazhab yang mengantarkan seseorang pada sikap fanatik. Sikap fanatik ini yang memecah belah masyarakat, melemahkannya serta menjadi penghalang lahirnya kebangkitan. Melalui ilmu dan menyebarkannya, seseorang bisa meraih kebahagiaan dunia dan akhirat. AsySyaukāni menganggap menuntut ilmu sebagai ibadah. Ketika menuntut ilmu dinilai ibadah, maka semua orang dituntut untuk belajar. Di antara solusi yang ditawarkan asy-Syaukāni untuk mengatasi problematika masyarakat Yaman saat itu adalah Negara menentunkan -menunjuk- pengajar pada tiaptiap desa untuk mengajarkan kepada manusia tentang agama mereka serta mengenalkan hak dan kewajibannya. Hal ini beliau cetuskan setelah lama menganalisa realitas yang terjadi di Yaman dan mengidentifikasi persoalannya, sehingga sampai pada kesimpulan bahwa solusi untuk mengatasi problem tersebut adalah melakukan penyebaran pendidikan, memperbaiki para qadhi dan beberapa persoalan lainnya.

Cirikhas pemikiran pendidikan asy-Syaukāni adalah beliau sangat lantang meminta para guru -pendidik- untuk mengamalkan ilmunya dan menyebar luaskannya kepada masyarakatnya. Sehingga, tidak hanya teori saja yang disampaikan tetapi juga diaplikasikan dan diamalkan (asy-Syaukāni, 1994: 71). 
h. Pendidikan untuk kaum hawa

Asy-Syaukāni memang tidak secara terang-terangan mengajak supaya perempuan diwajibkan untuk belajar, melainkan kewajiban belajar yang didengungkan beliau bersifat umum, tidak mengkhususkan untuk laki-laki saja, atau sebaliknya hanya kepada perempuan saja. Beliau memaksai ungkapan umum yang mencakup laki-laki dan perempuan. Bahkan, ketika menggunakan ungkapan laki-laki (muzakar) di beberapa tempat, tapi yang dimaksud beliau adalah kedua jenis kelamin tersebut. Sebagaimana kaidah ini berlaku dalam tata bahasa Arab. Ketika al-Qur'an mengatakan "qul hal yastawi alladzi ya'lamun wa alladzi la ya'lamun (QS. Az-Zumar: 9) meski secara tekstual menunjuk pada muzakar, tapi pada hakikatnya menunjuk pada kedua jenis kelamin; laki-laki dan perempuan. Asy-Syaukāni ketika menuntut diberlakukannya pendidikan secara menyeluruh sebagai solusi atas 'penyakit' yang menimpa masyarakatnya, beliau mengatakan kepada para pejabat hukkam - supaya masing-masing desa ditunjuk seorang guru yang salih yang mengajarkan para 'penduduk'nya ilmu-ilmu agama dan menyuruh mereka rutin menjalankan shalat di awal waktu (asy-Syaukāni, 1994: 61). Seorang guru yang salih dituntut mengajarkan ilmu agama kepada para penduduknya. Kata 'penduduk' di sini tentu mencakup laki-laki dan perempuan, bukan dikhususkan kepada salah satu dari keduanya.

Asy-Syaukāni dikenal sangat adil terhadap perempuan dan memberikan hak-haknya. Hal ini bisa dilihat dari kebijakan dan keputusan beliau selama bekerja sebagai qadhi - hakim-. Berikut ini beberapa sikap beliau pembelaaan beliau terhadap perempuan (asySyarji, 1988: 347-352).

1) Membela hak perempuan dalam warisan. Pada waktu itu, sebagaian penduduk Yaman tidak memberikan hak waris kepada perempuan melalui wasiat zalim yang dibuat sebelum kematian si pewaris. Tradisi seperti ini dihapus oleh asy-Syaukāni. Beliau mengajak semua muslim untuk membatalkan perkara ini, sebab ia termasuk kemunkaran yang paling keji dan termasuk tradisi Jahiliyyah. 
2) Keputusan asy-Syaukāni yang menyatakan bahwa perempuan memiliki hak tasarruf (transaksi). Dalam artian, transaksi jual beli seorang perempuan dengan orang lain dianggap sah. Jika perempuan mengaku dizalimi dalam satu kasus, maka pengakuannya diterima jika memang sesuai kenyataannya.

3) Asy-Syaukāni menyuarakan supaya diberlakukan adanya jaminan yang bisa menjaga kepemilikan perempuan. Sebab, watak perempuan yang lemah lembut sangat mungkin ditipu pihak lain. Oleh karena itu, asy-Syaukāni menyeru harus ada unsur kerelaan yang sebenarnya dari pihak wanita bila menggantikan tasarruf si perempuan.

i. Memperbaiki metode pembelajaran

Metode atau cara memiliki peran penting dalam tercapainya tujuan pembelajaran. Metode pembelajaran diartikan sebagai semua bentuk upaya yang dilakukan oleh seorang guru dalam membantu siswa untuk mencapai perubahan prilaku yang diharapkan sehingga hal ini dapat membantu mereka dalam menerima informasi, pengetahuan, kecakapan, orientasi dan nilai yang diinginkan (asy-Syaibani, 1985: 78). Dari definisi ini dapat digaris bawahi adanya keterkaitan antara metode dengan tujuan pendidikan.

Para pakar pendidikan Muslim, di antaranya Ibnu Khaldun menegaskan betapa bernilainya sebuah metode dalam pengajaran. Sebab, mengajar menurutnya merupakan sebuah kratifitas, dan kreatifitas ini dituntut ilmu di dalamnya (Ibnu Khaldun, 1981: 154). Kegagalan dalam mengkreasi pengajaran mengakibatkan para siswa tidak ada yang bisa menerima pembelajaran dengan senang hati. Jika mereka belajar dengan metode yang monoton yang tidak memperhatikan kecenderungan mereka maka tentu saja tidak bisa membentuk jiwa kekritisan siswa, sekaligus mereka tidak mampu mengurai problematika yang dihadapi. Sehingga dengan demikian, output atau alumni yang dihasilkan pun tidak mampu memenuhi apa yang dibutuhkan dalam rangka menciptakan sebuah kebangkitan. Untuk menciptakan sebuah kebangkitan, dibutuhkan pengembangan pengajaran yang universal. Di antara pengembangan ini adalah menumbuh kembangkan minat mengajar, mengembangan kemampuan guru dalam belajar mandiri serta menumbuhkan kecintaan 
dalam mengembangkan potensi, keilmuan dan pengetahuan (Abdullah, 1999: 132).

Imam asy-Syaukāni menyadari betul pentingnya metode dan gaya dalam proses pembelajan. Beliau juga yakin bahwa sebuah kebangkitan menuntut adanya metode dan gaya baru dalam mengajarkan ilmu pada anak-anak.

Pada era asy-Syaukāni, pembelajaran cenderung bersifat klasikal. Yaitu setelah siswa mengkhatamkan Alquran, baik secara bacaan maupun tajwidnya pada seorang Syaikh, ia kemudian melanjutkan pada jenjang berikutnya, yaitu berguru pada seorang Syaikh secara rutin pada halaqah (kajian) di masjid-masjid atau madrasah dengan mengkaji berbagai macam ringkasan matan kitab. Siswa tersebut mendengarkan penjelasan Syaikh dan sesekali menanyakan yang tidak difahaminya. Model pembelajarannya bersifat stagnan seperti ini, sampai Syaikh tersebut mengizinkan muridnya untuk meriwayatkan hadis atau kitab pada disipilin ilmu tertentu (al-Umari, 1990: 78). Imam asy-Syaukāni mencoba mengubah metode ini dengan membuat metode dan gaya baru dalam proses belajar mengajar sehingga lebih efektif. Berikut ini metode pembelajaran efektif menurut asy-Syaukāni (Muqbil, 1989: 88-95).

1) Memperhatikan perbedaan individu

Salah satu faktor keberhasilan seorang guru dalam mengajar adalah kemampuannya dalam memahami karakter masingmasing siswanya. Sebagaimana dimaklumi, para siswa tidak mungkin memliki tingkat kecerdasan dan pemahaman yang sama. Hal ini sejalan dengan apa yang dikatakan oleh pakar pendidikan tentang perlunya memperhatikan perbedaan karakter siswa selama proses belajar mengajar. Hal ini juga senada dengan pendidikan Islam yang menegaskan adanya perbedaan tingkat masing-masing individu. Sebagaimana ditegaskan dalam al-Quran, "Dan Dialah yang menjadikan kamu penguasa-penguasa di bumi dan Dia meninggikan sebahagian kamu atas sebahagian (yang lain) beberapa derajat." (QS. Al-An'am: 165). Inilah yang ditangkap oleh asySyaukāni, sehingga beliau menyatakan bahwa pemanfaatan materi ajar berbeda-beda tergantung pada tingkat 
pemahaman siswa. Terkadang materi yang disampaikan bisa ditangkap dengan mudah oleh mereka yang memiliki kecerdasan dan pemahaman, tapi tidak oleh mereka yang memiliki pemahaman yang kurang (asy-Syaukāni, 1988: 147). Melihat fenomena ini, maka asy-Syaukāni memberi penjelasan tentang bagaimana berinteraksi dengan tingkat manusia ketika mendidik dan mengajar mereka sesuai dengan karakter individu yang membedakan satu dengan yang lainnya.

2) Memperhatikan motivasi siswa

Dalam kitabnya, asy-Syaukāni tidak menggunakan kata 'motivasi' (ad-dafi'iyyah), melainkan kata-kata yang semakna dengannya, semisal ar-raghbah, al-maqashid dan al-azimah. Asy-Syaukāni memahami betul pentingnya motivasi dalam belajar, sehingga beliau memotivasi mereka bahwa orang yang menuntut ilmu akan meraih derajat yang tinggi di dunia dan akhirat (asy-Syaukāni, 1988: 147).

3) Bertahap dalam menuntut ilmu

Ilmu saling terkait satu sama lain, dan saling menyempurnakan. Asy-Syaukāni berpendapat, pembelajaran yang baik adalah penyampaian materi yang bertahap, dimulai dari yang mudah ke yang susah, dengan memperhatikan prioritas pada setiap disiplin ilmu. Jika seorang guru mengabaikan hal ini maka dapat menyebabkan anak didiknya membenci ilmu. Pengajar yang rabbani adalah mereka yang mendidik anak didiknya dari ilmu yang sederhana sebelum ilmu yang rumit (asySyaukāni, 1988: 149).

4) Belajar pada orang yang ahli di bidangnya

Seorang pelajar seharusnya menimba ilmu dari pakarnya, bukan kepada yang lain. Sebab, mereka orang yang tahu betul seluk beluk ilmu tersebut.

5) Mengamalkan ilmu

Sempurnanya ilmu bisa dilihat dari aplikasinya. Ilmu tanpa diamalkan ibarat pohon tak berbuah. Buah ilmu adalah amal, sehingga apa yang dipelajarinya benar-benar menancap dalam ingatannya. Jika tidak diamalkan, ilmu akan hilang dan lupa. Dalam pandangan asy-Syaukāni, orang yang tidak 
mengamalkan ilmunya, maka ilmunya menjadi cobaan dan bala' bagi dirinya. Dan orang bodoh jauh lebih mulia dari padanya (Asy-Syaukāni, 1988: 151).

6) Mengembangkan berfikir ilmiah

Asy-Syaukāni memperhatikan betul ruang kelas yang hidup. Hal ini menurut beliau diperlukan dalam rangka mengembangkan pola pikir ilmiah yang didasari pada pemahaman, kritik dan tidak taklid (asy-Syaukāni, 1988: 152). Metode ini mengembangkan pola pikir independen yang bisa menjadikan seorang siswa berkarya dan melakukan pembaruan. Tentu saja hal ini merupakan asas penting dalam meraih kebangkitan dan kemajuan.

7) Pentingnya keaktifan siswa

Proses pembelajaran memerlukan kerjasama positif dan optimisme berkelanjaran dari guru dan siswa. AsySyaukāni menekankan betul pentingnya hal ini dalam proses pendidikan. Ia menasihati, seorang pelajar harus memiliki cita-cita tinggi, tidak rela dirinya di posisi (rangking) rendah, dan tidak cukup belajar tanpa memilki tujuan. Semua ini tidak akan terjadi tanpa ada kesusngguhan dan keaktifan siswa (asy-Syaukāni, 1988: 154).

Adapun metode pembelajaran yang terdapat dalam kitab Adab ath-Thalab karya asy-Syaukāni sangat banyak, misalnya penelitian, debat, sanggahan, diskusi, kritik dan lain sebagainya. Ada pula metode lainnya yang erat berkaitan langsung menciptakan generasi pembelajar yang memiliki kemampuan meneliti, mengkaji dan mengeluarkan karya. Model generasi seperti inilah yang dibutuhkan oleh setiap bangsa yang menginginkan sebuah kebangkitan. Berikut ini metode yang dipaparkan asy-Syaukāni.

1) Belajar mandiri

Asy-Syaukāni menamai belajar mandiri dengan istilah al-wijadah. Metode ini dipaparkan pada bab khusus dengan metodologi pelajar tingkat pertama di mana si pelajar memelajari otodidaks kitab-kitab para Syaikh yang tidak ditemukan di Yaman (asySyaukāni, 1988: 154). Hal ini bisa dilakukan jika si pelajar memiliki motivasi belajar yang tinggi. Asy-Syaukāni mendorong siswanya supaya memiliki motivasi untuk belajar mandiri sesuai 
kemampuan dan persiapannya (asy-Syaukāni, 1988: 156).

2) Melakukan percobaan

Asy-Syaukāni mengajak supaya melakukan percobaan untuk sampai pada sebuah hakikat. Sebab, pengalaman dari hasil percobaan dinilai lebih efektif dan membekas.

3) Dikte

Asy-Syaukāni meyakini bahwa dikte tidak dapat mengembangkan kecakapan belajar. Oleh karenanya, setelah belajar melalui dikte, asy-Syaukāni mencari tahu kecapakan tersebut dengan cara bertanya kepada ayahnya tentang cara paling bagus yang bisa mengeluarkan siswa dari belengggu taklid yang didapat dari sistem belajar dikte yang tidak bisa membedakan antara yang rajih dan marjuh. Ayahnya kemudian memotivasi beliau supaya menguasai kecakapan kritik, analisa, dan penilaian yang ujungnya mampu membedakan yang rajih dan yang marjuh. Setelah menguasai kecakapan ini, asy-Syaukāni menyarankan para siswanya agar berupaya menguasai kecakapan ini sebagaimana yang dilakukannya (asy-Syaukāni, 1988: 178).

4) Gaya menghafal Asy-Syaukāni berpendapat, metode ideal dalam pembelajaran dimulai dari hafalan kemudian pemahaman. Sehingga pelajar di samping menguasai hafalan, sekaligus paham apa yang dihafalnya. Dengan mengulang-ulang materi yang diajarkan sampai benar-benar hafal sehingga hal itu meminimalisir kekeliruan (asy-Syaukāni, 1988: 180).

Abdul Ghani Abud menjelaskan pentingnya metode ini merujuk pada tiga alasan berikut (Abud, 1982: 56-63).

1) Gaya menghafal termasuk ciri khas pembelajaran Islam sepanjang sejarah, dan metode ini telah berhasil mencetak para ulama dan ilmuan besar di berbagai disipilin ilmu.

2) Penghapusan gaya ini merupakan salah satu tujuan orientalis yang berupaya keras memerangi Islam. Caranya adalah menganggap sepele gaya ini sehingga umat Islam tidak lagi mau menghafal al-Qur'an.

3) Akibat propaganda ini, gaya ini dalam pandangan sebagian kaum muslimin yang terpengaruh pendapat orientalis di atas menganggap sebagai gaya yang terbelakang dan tidak sejalan dengan pendidikan modern. Abud mengisyaratkan bahwa 
baru-baru ini terdapat penelitian yang menyatakan tentang efektifnya gaya ini dan berperanguh positif dalam proses pembelajaran. Di antaranya penelitian yang diadakan di Kongo tahun 1960 (Abud, 1982: 65).

Sebagaimana dimaklumi, jika si pelajar melewatkan hafalan pada usia dini, maka sangat sulit baginya menghafal di usia dewasa. Sehingga, metode ini jangan sampai dilupakan pada usia dini. Adapun pemahaman tidak terdapat pada fase-fase pertama dalam belajar. Melainkan, seorang pelajar baru bisa membedakan informasi yang beraneka ragam pada usia-usia tertentu. Oleh karenanya, menghafal matan pada usia-usia dini sangat diperlukan. Hal ini difahami betul oleh asy-Syaukāni, sehingga beliau mengisyaratkan supaya pelajar menghafal ringkasan-ringkasan kitab matan pada tahap pertama belajarnya yang kemudian ditindak lanjuti dengan pemahamana pada tahapan berikutnya.

\section{Simpulan}

Keterbelakangan yang menimpa dunia Islam, khususnya di Yaman merupakan faktor yang mendorong para pemikir Islam, di antaranya asy-Syaukāni untuk memikirkan dan mencari solusi bagaimana bangkit dari keterpurukan ini kepada situasi yang lebih baik. Inilah yang dilakukan oleh para pemimpin dan pemikir di mana pun berada. Keterbelakangan yang menimpa umatnya secara spontanitas mendorongnya untuk mengubah bangsanya, terlebih lagi jika ada model yang bisa dijadikan perbandingan oleh para pemikir tersebut, lalu diikuti kemudian mengunggulinya jika memungkinkan. Islam dahulu maju lantaran banyak mengadopsi peradaban-peradaban bangsa lain dan mengembangkannya. Barat sekarang ini maju juga karena mengadopsi peradaban bangsa lain yang maju, yang saat itu adalah Islam. Dengan kata lain, jika suatu bangsa hendak maju maka haruslah terbuka dengan peradaban lain dan mengoptimalkan betul anugerah akal yang diberikan Tuhan. Inilah yang ditekankan oleh asy-Syaukāni. Sehingga, dalam banyak karyanya beliau sangat getol memerangi taklid dan mewajibkan ijtihad. Beliau juga menolak keras 
Pemikiran Pendidikan Asy-Syaukāni ...

bersikap jumud dan fanatis. Sebab, jika suatu bangsa lebih nyaman berada dalam zona taklid dan fanatik maka kemajuan bangsa hanya sebuah angan belaka. 


\section{DAFTAR PUSTAKA}

Abdul Daim, Abdullah. 1978. at-Tarbiyyah Ibra at-Tăikh. cet.3. Beirut: Dar al-Ilm li al-Malayin.

Abud, Abdul Ghani. 1982. al-Fikr at-Tarbawi Inda al-Ghazāli Kamā Yabdu min Dirāsatihi. Kairo: Dar al-Fikr al-Arabi.

Bukrusyah, Halimah, 2002. Máalim Tajdid Manhaj al-Fiqhi: anmudzaj asy-Syaukāni. cet-1. Doha: Wizārah al-Auqaf wa asy-Syuun adDiniyyah.

Grolier incorporate, 1983. The New Book of Knowledge. Library of Congress.

Ibnu Khaldun, Abdurrahman. 1981. Muqaddimah Ibnu Khaldun. cet. 1.

Beirut: Dar al-Fikr li ath-Thiba'ah wa an-Nasyr.

Maqalih, Abdul Aziz. 1982. al-Yaman al-Islami: qiraah fi Fikr azZaidiyyah wa al-Mu'tazilah. cet-1. Beirut: Dar al-Audah.

Muqbil, Shalih Muhammad. 1989. Muhammad bin Ali asy-Syaukāni wa Juhüdu at-Tarbawiyyah. cet.1. Beirut: Dar al-Jil.

Syarji al, Abdul Ghani Qasim. 1988. al-Imām asy-Syaukāni: Hayatuhu wa Fikruh. cet-1. Beirut: Muassasah ar-Risalah.

Syaibani asy-, Umar. 1985. Falsafah at-Tarbiyyah al-Islamiyyah. cet-5. Maroko: al-Mansyaah al-Ammah li an-Nasyr wa at-Tauzi' wa alI'lan.

Syaukāni al, Muhammad Ali, 1988. Adab ath-Thalab wa Muntaha alArab. cet-1. Kairo: Maktabah al-Quran. , 1929. al-Badr at-Tāali' bi Mahāasin Man Ba'd al-Qarn as-Sabi'. cet-1. Kairo: Dar as-Sa'adah. , 1994. ar-Rasā' 'il as-Saläfiyyah fi Ihyä' Sunnah al-Bariyyah. cet-3. Beirut: Dar al-Kutub al-Arabi. 